\title{
Pelvic hydatid: the great masquerader
}

\author{
Siddharth Pandey, Vishwajeet Singh, Rahul Janak Sinha, Ashish Sharma
}

Department of Urology, King George's Medical University, Lucknow, Uttar Pradesh, India

\section{Correspondence to} Dr Siddharth Pandey, sid1420@gmail.com

Accepted 30 September 2018

\section{DESCRIPTION}

A 52-year-old man presented with urinary frequency and occasional lower abdominal pain for 4 months. His uroflow study and postvoid residual urine were normal and his digital rectal examination had grade 2 prostatic enlargement. His urinary symptoms were attributed to benign prostatic hyperplasia, and he was prescribed tamsulosin $(0.4 \mathrm{mg})$ and solifenacin $(5 \mathrm{mg})$ for his symptoms. One week later he only had partial relief of symptoms, thus an ultrasound was done that showed a cystic lesion abutting the urinary bladder in the region of right iliac fossa (figure 1). A contrast-enhanced CT (CECT) scan was then done, which showed a cystic lesion $(3.8 \times 4 \mathrm{~cm})$ with enhancing internal septa and peripheral wall enhancement abutting the urinary bladder (figure 2). There was no other cyst in the abdomen so a provisional diagnosis of primary pelvic peritoneal hydatid cyst was made. We then carried out a cystoscopy to ascertain there was no communication of the cyst with the urinary bladder. Cystoscopically the external compression by the hydatid cyst on the urinary bladder could be demonstrated (figure 3 ). The patient was advised surgical removal of the primary pelvic hydatid cyst. Preoperatively he was given albendazole $400 \mathrm{mg}$ twice daily for 7 days and then the cyst was removed (figure 4). Postoperatively albendazole was continued for 3 weeks and after a gap of 2 weeks another 28-day course of albendazole was given. The patient is doing fine 4 months post surgery, and his urinary symptoms have resolved.

The tapeworm Echinococcus granulosus most commonly causes hydatid disease in humans. Liver followed by the lungs is the most commonly affected organs. Pelvic hydatid cysts are rare and can be either primary or secondary. Secondary pelvic hydatid cysts are more common and occur following rupture of primary hepatic, splenic or

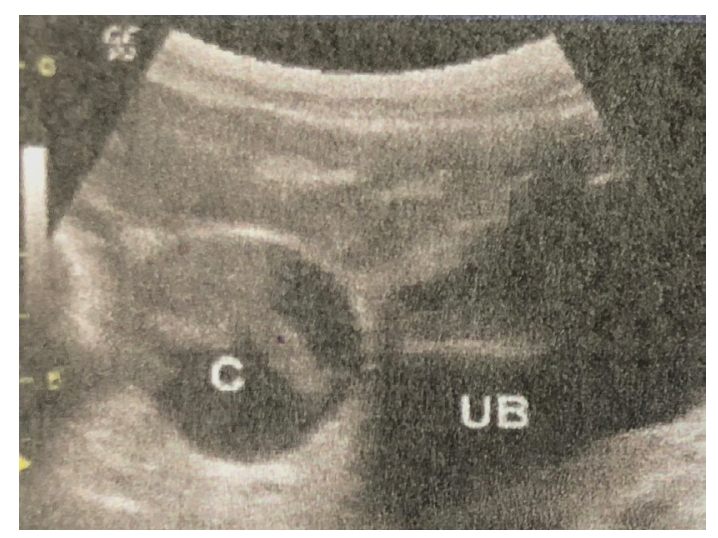

Figure 1 Ultrasound showing the cyst (C) abutting the urinary bladder (UB).

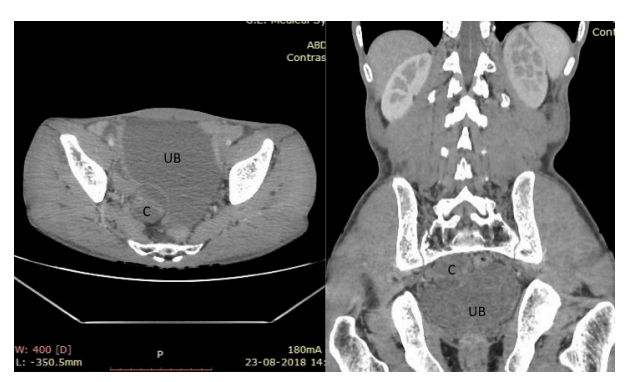

Figure 2 Contrast-enhanced CT showing the cyst (C) compressing the urinary bladder (UB) in transverse and coronal sections.

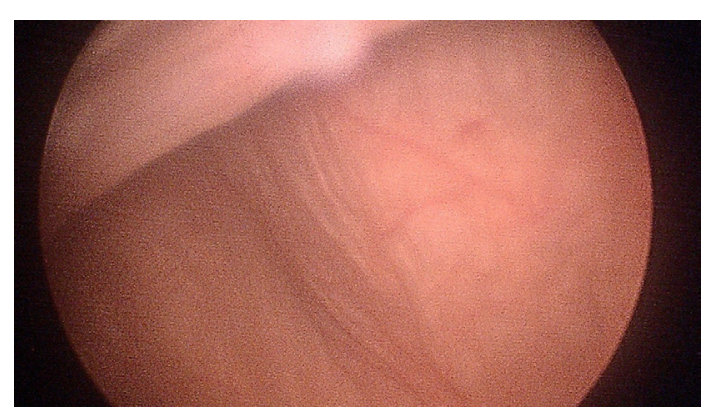

Figure 3 Cystoscopic view of the external compression by the cyst on the urinary bladder.

mesenteric hydatid cysts. When there is no other associated cyst in the abdomen, the pelvic hydatid cyst is said to be primary. ${ }^{1}$ In a pelvic hydatid cyst, the presenting symptoms are usually due to its mass effects. It may be confused with obstructive uropathy (due to compression of urinary tract), ovarian cysts or even appendicitis and pelvic sepsis (when they rupture). An ultrasound followed by a CECT scan is usually required for diagnosing this condition. MRI in most instances is not required as it does not offer much advantage over CECT. ${ }^{2}$ The best treatment for this condition is surgical excision followed by chemotherapy with albendazole or

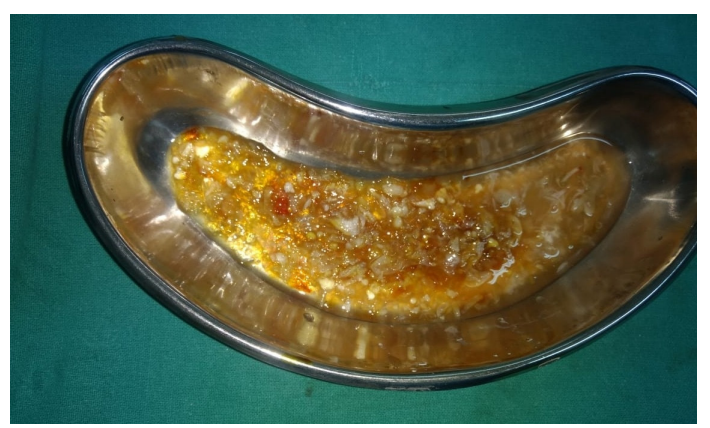

Figure 4 The removed cyst was opened with multiple daughter cysts within it. 


\section{Learning points}

Pelvic peritoneal hydatid cysts are rare and may be primary or secondary, but they have non-specific presentation usually due to its mass effect on adjacent organs and on initial workup the patients symptoms may not be attributed to them.

- The best treatment is preoperative chemotherapy with albendazole or mebendazole followed by surgical excision and postoperative chemotherapy.

mebendazole. Usually albendazole is given at a maximum dose of $800 \mathrm{mg} /$ day for 28 days. This course is repeated after a drugfree period of 14 days. Preoperative chemotherapy for 7 days is usually recommended. ${ }^{3}$
Contributors SP conceived the case report. SP and VS were major contributors towards the writing of the manuscript. VS, RJS and SP treated the patient and also interpreted the patient data. SP and AS were involved in the review. All authors read and approved the final manuscript.

Funding The authors have not declared a specific grant for this research from any funding agency in the public, commercial or not-for-profit sectors.

Competing interests None declared.

Patient consent Obtained.

Provenance and peer review Not commissioned; externally peer reviewed.

\section{REFERENCES}

1 Parray FQ, Wani SN, Bazaz S, et al. Primary pelvic hydatid cyst: a case report. Case Reports in Surgery; 2011:3.

2 el-Tahir MI, Omojola MF, Malatani T, et al. Hydatid disease of the liver: evaluation of ultrasound and computed tomography. Br J Radiol 1992;65:390-2.

3 Brunetti E, Kern P, Vuitton DA. Expert consensus for the diagnosis and treatment of cystic and alveolar echinococcosis in humans. Acta Trop 2010;114:1-16.

Copyright 2018 BMJ Publishing Group. All rights reserved. For permission to reuse any of this content visit

http://group.bmj.com/group/rights-licensing/permissions.

BMJ Case Report Fellows may re-use this article for personal use and teaching without any further permission.

Become a Fellow of BMJ Case Reports today and you can:

- Submit as many cases as you like

- Enjoy fast sympathetic peer review and rapid publication of accepted articles

- Access all the published articles

Re-use any of the published material for personal use and teaching without further permission

For information on Institutional Fellowships contact consortiasales@bmjgroup.com

Visit casereports.bmj.com for more articles like this and to become a Fellow 